ISSN 0258-7122 (Print), 2408-8293 (Online)

Bangladesh J. Agril. Res. 41(2): 195-205, June 2016

\title{
EFFECT OF DROUGHT STRESS ON GAS EXCHANGE CHARACTERISTICS OF FOUR SOYBEAN GENOTYPES
}

\author{
J. A. CHOWDHURY ${ }^{1}$, M. A. KARIM ${ }^{2}$, Q. A. KHALIQ ${ }^{2}$ \\ A. U. AHMED ${ }^{3}$ AND M. S. A. KHAN ${ }^{1}$
}

\begin{abstract}
An experiment was conducted in a venylhouse at the environmental stress site of Bangabandhu Sheikh Mujibur Rahman Agricultural University, Gazipur during September to December 2012 to determine the changes of photosynthesis and some related traits under drought stress in soybean genotypes. Four studied genotypes viz. Shohag, BARI Soybean 6 and BD2331 (relatively stress tolerant) and BGM2026 (susceptible) were tested against two water regimes such as water stress and non-stress. Results indicated that gas exchange characteristics were positively correlated with plant growth. Photosynthesis and stomatal conductance showed more reduction in susceptible genotypes than the tolerant ones. Transpiration rate was found minimal in tolerant genotypes. Changes in leaf growth attributes of the four selected genotypes were compared under drought (water) stress conditions which is one of the major plant parts related to gas exchange. Generally, drought stress decreased the leaf area more in susceptible genotype than tolerant genotype. From the result, genotype BGM2026 which recorded the lowest photosynthesis, stomatal conductance, leaf area but highest transpiration rate was considered as drought susceptible whereas BARI Soybean-6, Shohag and BD2331 were more drought stress tolerant which have better mechanisms of drought tolerance.
\end{abstract}

Keywords: Soybean, drought, photosy on thesis, transpiration, stomabal conductance.

\section{Introduction}

Drought stress is one of the serious environmental factors affecting plant growth, development, yield and quality. It induces various physiological and biochemical adaptations in plants. Among physiological processes gas exchange processes is one of the most important processes and this process of tolerant and susceptible genotypes responded dissimilarly under stress conditions. Lawlor and Cornic (2000) and Zhu (2002) reported that drought affects the morpho-physiological, biochemical and molecular processes in plants resulting in growth inhibition, stomata closure with consecutive reduction of photosynthesis, transpiration, decrease in chlorophyll content and inhibition of photosynthesis and protein changes to cope with osmotic changes in their tissues. The productivity of the crop may be related to physiological attributes like transpiration rate,

\footnotetext{
${ }^{1}$ Senior Scientific Officer, Agronomy Division, Bangladesh Agricultural Research Institute (BARI), Gazipur-1701, ${ }^{2}$ Professor, Department of Agronomy, Bangabandhu Sheikh Mujibur Rahman Agricultural University (BSMRAU), Gazipur-1706, ${ }^{3}$ Principal Scientific Officer, Plant Pathology Division, BARI, Gazipur-1701, Bangladesh.
} 
photosynthetic rate etc. Water stress inhibits cell enlargement more than cell division. It reduces plant growth by affecting photosynthesis, respiration, translocation, ion uptake, carbohydrates and nutrient metabolism and growth promoters (Farooq et al., 2009). Drought reduces leaf expansion (Alves and Setter, 2004), accelerates leaf senescence (De Souza et al., 1997) and leads to death of leaf tissue. The adaptive potential of some plant species reducing water losses were achieved by closing of stomata and reduction in the transpiration rate (Tardieu and Davies, 1996). Hence, measurement of transpiration rate is an excellent tool to assess drought tolerant capacity of crop plants. Soybean is one of the sensitive crop to several abiotic stress as compared to many other legumes though variability in tolerance among its genotypes is very common (Silveria et al., 2003). Among different stresses one of the most important stresses that affects plant growth is drought stress. This study was, therefore, initiated to determine the changes of photosynthesis and some related traits in soybean under drought stress situation.

\section{Materials and Method}

A pot experiment in a vinyl house was conducted at the Bangabandhu Sheikh Mujibur Rahman Agricultural University, Salna, Gazipur during September to December 2012. Three relatively water stress tolerant (Shohag, BARI Soybean 6 and BD2331) and one susceptible (BGM 2026) genotypes, selected from the previous experiment, were used in this study to determine the changes of photosynthesis and some related traits in soybean under drought stress at vegetative and pod development stages. Seeds of tolerant genotypes and susceptible genotypes were sown in plastic pots $(24 \mathrm{~cm}$ internal diameter and 30 $\mathrm{cm}$ height). The pot was filled with mixture of soil and cow dung at a ratio of $4: 1$. Pot contained $12.0 \mathrm{~kg}$ of soil which was equivalent to $9 \mathrm{~kg}$ oven dry soil and holds about $28 \%$ moisture at field capacity (FC). Soil used in the pot was sandy

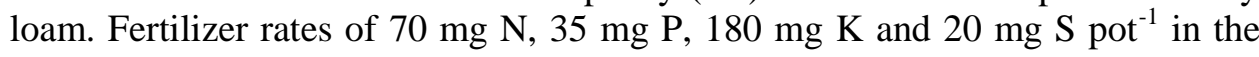
form of urea, triple super phosphate, muriate of potash and gypsum was added and well mixed with the soil before pouring into the pots. Six seeds pot $^{-1}$ were sown on 3 September, 2012. After seedling establishment two uniform and healthy plants pot $^{-1}$ were allowed to grow. Two watering treatments of the plants viz. drought stress i.e. water stress (50\% water of the FC) and non-stress i.e. control (80\% water of FC) were applied at 21 days after emergence (DAE) and maintained throughout the growing season. The pots were arranged in a completely randomized design under Factorial arrangement with four replications (two plants pot $^{-1}$ considered as one replication). There were four genotypes and two water regimes treatments (hereafter referred to as non-stress and water stress treatments) were included as variable treatments. Weeding and spraying were done as normal management practices for all the treatments. Some growth parameters such as leaf area, leaf weight, transpiration rate and gas exchange was measured which are described below: 


\section{Data collection}

\section{Leaf growth measurement}

Leaf samples were taken to determine leaf biomass accumulation at vegetative and pod development stages. At each sampling, leaves of two plants pot $^{-1}$ were removed and leaf area plant $^{-1}$ was measured by an automatic leaf area meter (AAM-8, Hayashi-denko, Japan). Leaves were oven dried at $70^{\circ} \mathrm{C}$ to a constant weight and dry weight taken. Specific leaf area (SLA) and specific leaf mass (SLM) were also measured.

Specific leaf area: Specific leaf area (SLA) is the ratio of leaf area to leaf dry weight. It is used to understand the quantity of plant tissue employed for photosynthesis per unit of leaf tissue. It was determined by the following formula:

$$
\text { SLA = } \frac{\text { Leaf area }}{\text { Leaf dry weight }}\left(\mathrm{cm}^{2} \mathrm{~g}^{-1}\right)
$$

Specific leaf mass: The specific leaf mass (SLM) indicates the leaf thickness, and it was determined by the following formula:

$$
\mathrm{SLM}=\frac{\text { Leaf dry weight }}{\text { Leaf area }}
$$

The transpiration rate and leaf gas exchange was measured at the pod development stage using a portable photosynthesis system (LICOR-6200).

The data were analyzed by MSTAT-C statistical package program. The difference between the treatments means were compared by Least Significant Difference (LSD) test (Gomez and Gomez, 1984). Functional relationship between stomatal conductance and photosynthesis was established through correlation and regression analyses by using Excel program.

\section{Results and Discussion}

\section{Photosynthesis}

Photosynthesis rate of four soybean genotypes grown under non-stress and water stress environment are presented in Fig. 1. Plants grown under water stress condition showed less photosynthesis than that grown under non-stress condition. Kawamitsu et al. (2000) reported that drought stress decreased the rate of photosynthesis in an intertidal algae and a land plant. Purwanto (2003) also reported that photosynthetic rate decreased as water stress was increased. Photosynthetic reduction due to drought was caused by a decrease in leaf expansion, impaired photosynthetic machinery, pre-mature leaf senescence and 
associated reduction in food production (Wahid and Rasul, 2005). The differences in photosynthesis between the non-stressed and water stressed plants were observed in all the genotypes but the difference was higher in BGM2026 than that of other genotypes. Photosynthetic rate ranged from 26.87 to 29.81 and 17.14 to $22.06 \mu \mathrm{mol} \mathrm{CO} \mathrm{C} \mathrm{m}^{-2} \mathrm{~s}^{-1}$ under non-stress and water stress conditions, respectively. The highest photosynthesis rate was observed in BARI Soybean 6 under non-stress condition followed by BGM2026 though the reduction percent was higher in BGM2026 (40.48\%). The other three genotypes (BARI Soybean 6, Shohag and BD2331) showed 25.97, 27.94 and 28.5\% reduction, respectively. The decreased photosynthesis under stress might be attributed partly due to reduced stomatal conductance (Nagy and Galiba, 1995), lowered transporation of photosyntahte (Hagemayer, 1997), reduction in protein concentration (Sibole et al., 1998), decline in photosynthetic pigment concentration (Kolchevskii et al., 1995), reduced carboxylase activity (Hagemayer, 1997) and inhibition of the light reaction mechanism (Unger, 1991). Drought stress may reduce plant photosynthesis by reducing leaf area, closing of stomata, and reducing the activity of dehydrated protoplasmic machinery (Boyer, 1976). Drought stress caused changes in photosynthetic pigments and components (Anjum et al., 2003), damaged photosynthetic apparatus (Fu and Huang, 2001) and diminished activities of Calvin cycle enzymes, which are important factors for reducing crop yield (Monakhova and Chernyadev, 2002). The less reduction of photosynthesis under stress condition was obviously helpful for maintaining better growth.

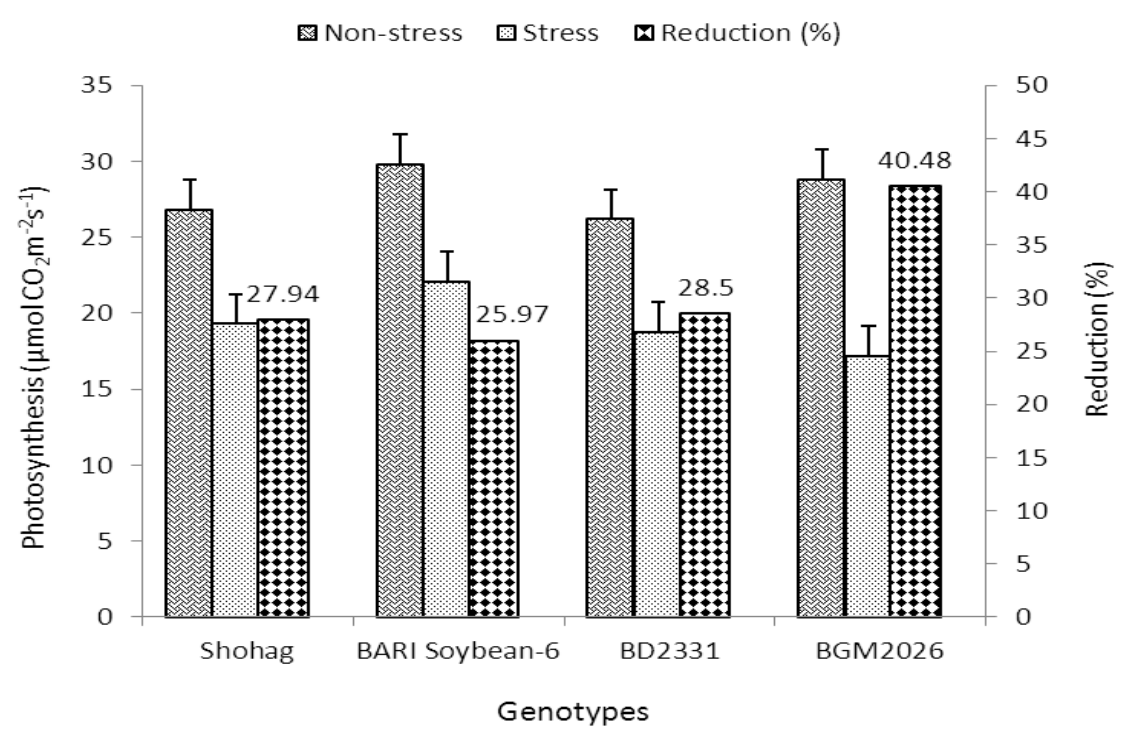

Fig.1 Photosynthesis rate and reduction $(\%)$ in four soybean genotypes grown under non-stress and water stress conditions at pod development stage. Vertical bars represent $\mathrm{LSD}_{(0.05)}$ value. 


\section{Stomatal conductance}

Stomatal conductance indicated the degree of exchange of $\mathrm{CO}_{2}$ and water vapor between ambient and inner leaf. Stomatal conductance decreased very quickly as soil dried (Atteya, 2003). Water stress condition significantly decreased the stomatal conductance of leaves in all the genotypes studied (Fig. 2). Decreased stomatal conductance due to water stress also observed in soybean leaves by Makbul et al. (2011). They reported that exposure to drought stress resulted in decreasing in stomatal conductance of $42 \%$ in drought stressed leaves as compared to the unstressed leaves. To survive over an extended drought period, it is important for the soybean leaves to adjust its stomatal conductance to prevent excessive water loss (Ku et al., 2013). Stomatal conductance ranged from 0.284 to 0.498 and 0.033 to $0.091 \mathrm{~mol}$ water $\mathrm{m}^{-2} \mathrm{~s}^{-1}$ under non-stress and water stress conditions, respectively. BARI Soybean 6 showed higher stomatal conductance followed by genotype BGM2026 under non-stress environment but the highest reduction in stomatal conductance occurred in BGM2026. The stomatal conductance of BGM2026 was 0.033 mol water $\mathrm{m}^{-2} \mathrm{~s}^{-1}$ which was much less than that of other three genotypes. The higher reduction of stomatal conductance in BGM2026 due to water stress might be attributed to the lower leaf water potential and a reduction in leaf relative water content, which resulted in loss of turgor vis a vis to reduced photosynthetic rate. In this study, stomatal conductance declined by 78.52 to $93.22 \%$ due to water stress. Stomatal conductance was decreased under water stress, and plants grown under drought condition had lower stomatal conductance in order to conserve water (Purwanto, 2003).

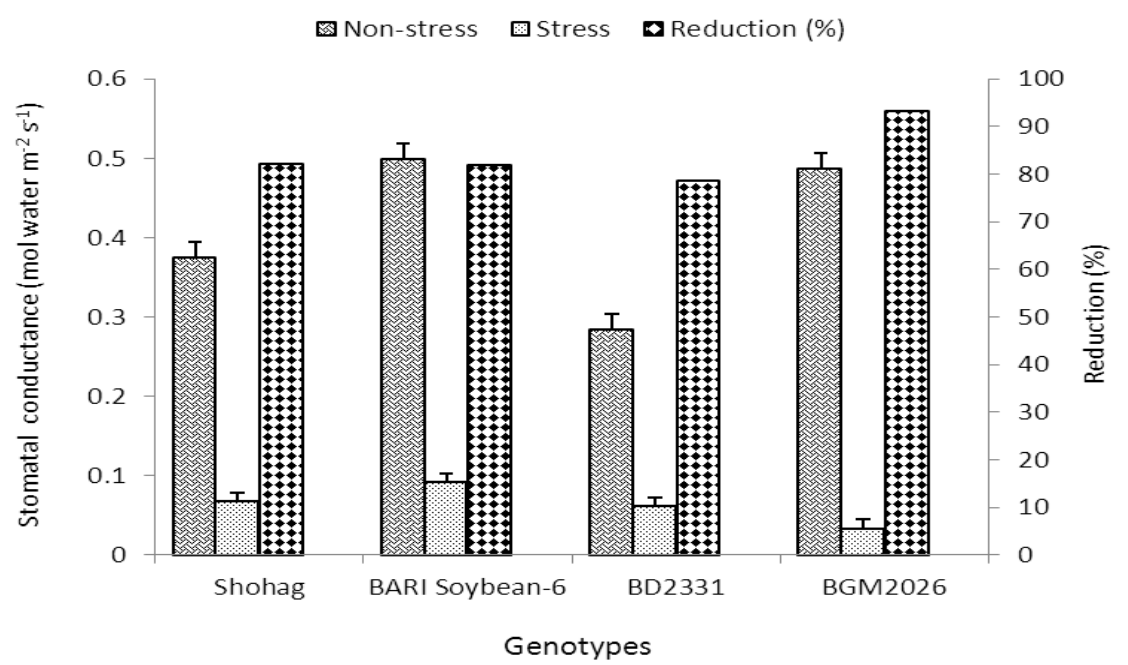

Fig. 2 Stomatal conductance and reduction (\%) in four soybean genotypes grown under non-stress and water stress conditions at pod development stage. Vertical bars represent $\mathbf{L S D}_{(0.05)}$ value. 
Stomatal conductance and photosynthetic rate of soybean genotypes showed a strong positive relationship ( $\mathrm{r}=0.97$; Fig. 3). A linear relationship between stomatal conductance and photosynthetic rate was observed at pod development stage indicating that higher the stomatal conductance greater was the photosynthetic rate. Ashraf and Iram (2005) reported that higher stomatal conductance in plants increased $\mathrm{CO}_{2}$ diffusion into leaf thereby favoring higher photosynthetic rate. However, both variables declined considerably under water deficit stress condition. Similar result was found in Phaseolus vulgaris and Sesbania aculeate by Ashraf and Iram (2005). Mafakheri et al. (2010) also reported that plants grown under drought condition had a lower stomatal conductance in order to conserve water and consequently, the $\mathrm{CO}_{2}$ fixation was reduced vis a vis photosynthetic rate decreased considerably.

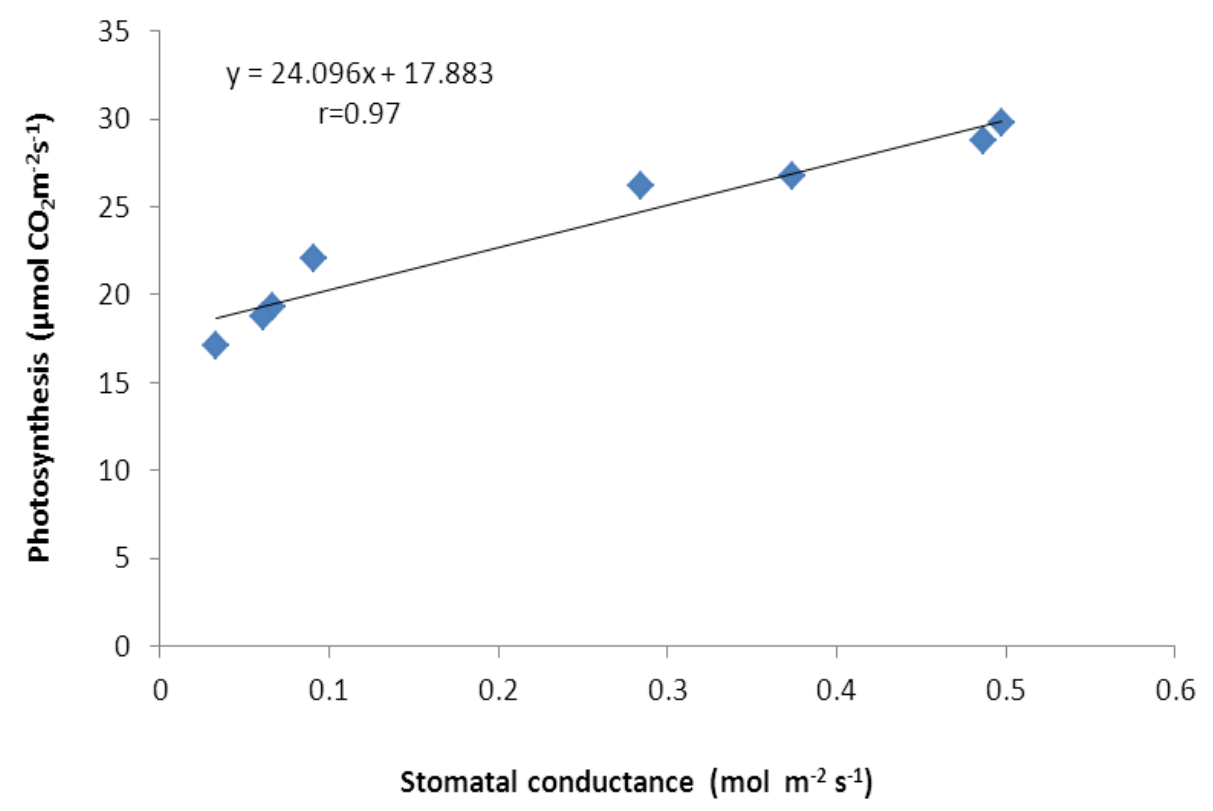

Fig. 3 Relationship between stomatal conductance and photosynthesis at pod development stage.

\section{Transpiration rate}

The effect of drought stress on transpiration rate was similar to that on photosynthesis. Transpiration rate in all the four soybean genotypes decreased with water stress (Fig. 4). Under water stress condition, genotype BGM2026 showed higher transpiration rate than the other genotypes. The reduction in transpiration rate was higher in BARI Soybean- 6 followed by Shohag while that was the least in the genotype BGM2026 (Fig. 4). Transpiration rate was 21, 31 
and 15\% lower in Shohag, BARI Soybean-6 and BD2331, respectively than the genotype BGM2026. Genotypes Shohag, BARI Soybean 6 and BD2331 presumably conserved more water than BGM2026. Transpiration rate ranged from 10.3 to $12.09 \mathrm{mmol}$ water $\mathrm{m}^{-2} \mathrm{~s}^{-1}$ under non-stress and 2.52 to $3.35 \mathrm{mmol}$ water $\mathrm{m}^{-2} \mathrm{~s}^{-1}$ under water stress conditions. In response to the water stress, the highest reduction in transpiration rate was observed in BARI Soybean 6 (78.38\%), while the lowest in BGM2026 (72.29\%) but close to BD2331 (72.71\%). Islam et al. (2004) reported that the decrease in transpiration under stress conditions may be considered as a drought avoidance mechanism in French bean.

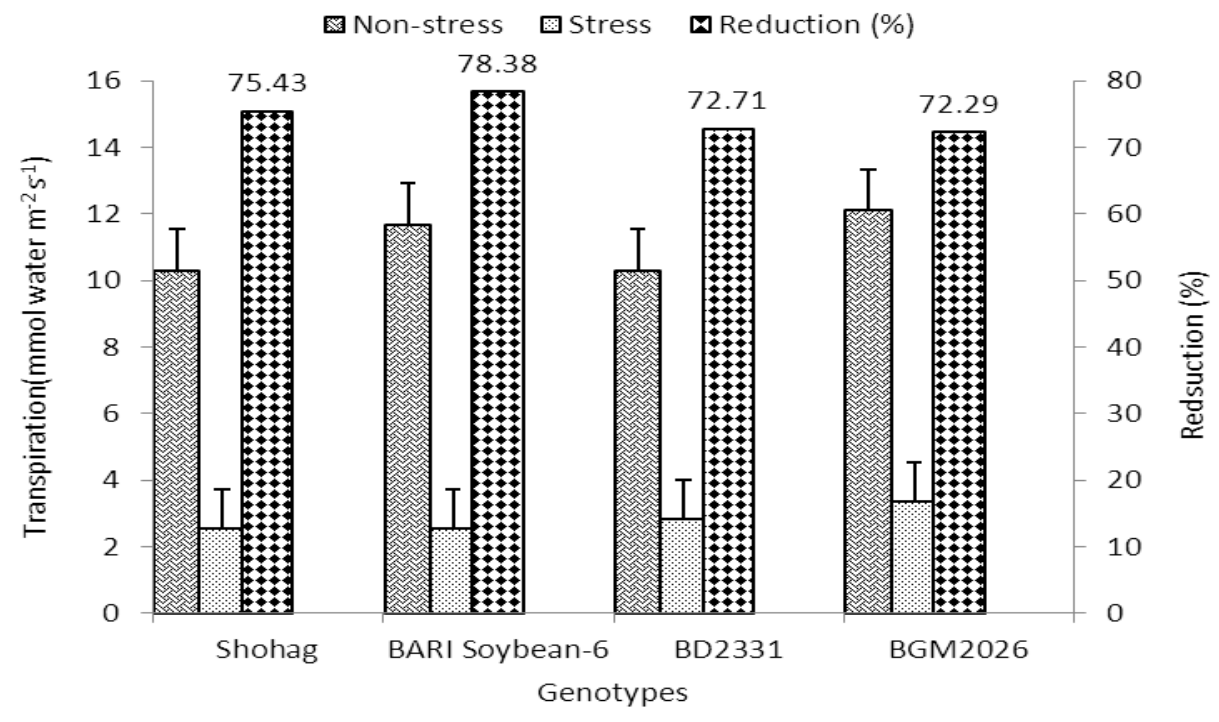

Fig. 4. Transpiration rate and reduction (\%) in four soybean genotypes grown under non-stress and water stress conditions at pod development stage. Vertical bars represent $\operatorname{LSD}_{(0.05)}$ value.

Avoidance of drought can be realized minimizing water loss by reduction of stomatal conductance or the transpiring leaf surface (Van den Boogaard et al., 1996). Leaf water use efficiency may be positively correlated with yield when water is a limiting factor for crop growth (Condon et al., 1990). The higher value of water use efficiency at the leaf level resulted from lower rates of transpiration rather than from higher rates of photosynthesis (Van den Boogaard et al., 1996).

\section{Leaf growth attributes}

Leaf area is the expression of cumulative cell expansion and division during leaf growth and plasticity in leaf area could be a means by which plants control water use under stress conditions. Leaf area of soybean genotypes subjected to drought 
stress was significantly lower than those that were not exposed to drought stress. Barrios et al. (2005) reported that leaf area of dry beans reduced when the plants expose to drought stress. In this experiment, leaf area in the four genotypes was strongly reduced by water stress (Tables 1 and 2). At vegetative stage, leaf areas of stressed plants were 87, 89, 88 and $74 \%$ of that of non stress plants of Shohag, BARI Soybean 6, BD2331 and BGM2026, respectively (Table 1). On the contrary, at pod development stage, the areas of water stressed plants were 71 , 72,70 and 55\% (Table: 2) of that of non-stressed of Shohag, BARI Soybean 6, BD2331 and BGM2026, respectively which indicated that the expansion of newer leaves was less under water stress condition compared to non-stress condition. Similar results were observed by Ocampo and Robles (2000) in mungbean. The reduction in leaf area as a result of drought stress is considered to be a drought adaptive mechanism whereby plant avoids becoming dehydrated. With the reduction of leaf area transpiration losses would also be minimized (Purwanto, 2003).

Table 1. Leaf area (LA), specific leaf area (SLA) and specific leaf mass (SLM) of four soybean genotypes at vegetative stage under two water regimes

\begin{tabular}{l|c|c|c|c|c|c}
\hline \multirow{2}{*}{ Genotypes } & \multicolumn{2}{|c|}{$\mathrm{LA}\left(\mathrm{cm}^{2}\right)$} & \multicolumn{2}{c|}{ SLA $\left(\mathrm{dm}^{2} \mathrm{~g}^{-1}\right)$} & \multicolumn{2}{c}{ SLM $\left(\mathrm{g} \mathrm{dm}^{-2}\right)$} \\
\cline { 2 - 7 } & $\begin{array}{c}\text { Non- } \\
\text { stress }\end{array}$ & $\begin{array}{c}\text { Water } \\
\text { stress }\end{array}$ & $\begin{array}{c}\text { Non- } \\
\text { stress }\end{array}$ & $\begin{array}{c}\text { Water } \\
\text { stress }\end{array}$ & Non-stress & $\begin{array}{c}\text { Water } \\
\text { stress }\end{array}$ \\
\hline Shohag & 651.52 & 569.16 & 3.25 & 3.21 & 0.306 & 0.314 \\
BARI Soybean 6 & 717.2 & 642.8 & 3.26 & 3.25 & 0.306 & 0.322 \\
BD 2331 & 625.6 & 552.7 & 3.23 & 3.19 & 0.308 & 0.313 \\
BGM 2026 & 711.12 & 526.31 & 3.15 & 3.09 & 0.316 & 0.323 \\
\hline LSD $_{(0.05)}$ S & \multicolumn{2}{c}{$* *$} & \multicolumn{2}{c}{ NS } & \multicolumn{2}{c}{ NS } \\
\multicolumn{1}{c}{ G } & 24.69 & \multicolumn{2}{c}{ NS } & \multicolumn{2}{c}{ NS } \\
\multicolumn{1}{c}{ SxG } & 34.91 & \multicolumn{2}{c}{ NS } & \multicolumn{2}{c}{5.77} \\
CV\% & \multicolumn{2}{c}{3.91} & \multicolumn{2}{c}{3.99} & \multicolumn{2}{c}{. }
\end{tabular}

$\mathrm{S}=$ Stress, $\mathrm{G}=$ Genotypes, $* *$ significant at $5 \%$ levels of probability, NS=not significant.

Specific leaf area (SLA) is an indirect measure of leaf thickness. SLA was not significantly affected during water stress at vegetative stage, though affected at pod development stage. Specific leaf area was slightly higher in non-stress condition, whereas specific leaf mass was higher in water stress condition. Coasta-Franca et al. (2000) reported that SLA was not significantly affected during 10 days drought in Phaseolus vulgaris. Mondal and Paul (1992) also reported that pre-flowering SLA of the irrigated plants of mustard was significantly higher than that of the rainfed mustard plants. The slightly lower SLA under water stress condition revealed that leaves were to some extent thick 
compared to that of non-stress condition. Specific leaf mass (SLM) was significantly affected during water stress at pod development stage. SLM indicates amount of photosynthetic tissues in a unit leaf area increased in response to water stress. An increase in SLM suggests that the water stressed plants may have accumulated dry matter in the leaves more when encountered water stress which is considered as an adaptive strategy to cope with the water stress situation. Higher SLW means high ratio of leaf weight to leaf area and it is indicative of plant ability to reduce water loss (Purwanto, 2003). According to Nobel (1980), increases in rate of photosynthesis have been correlated with increase in specific leaf mass.

Table 2. Leaf area (LA), specific leaf area (SLA) and specific leaf mass (SLM) of four soybean genotypes at pod development stage under two water regimes

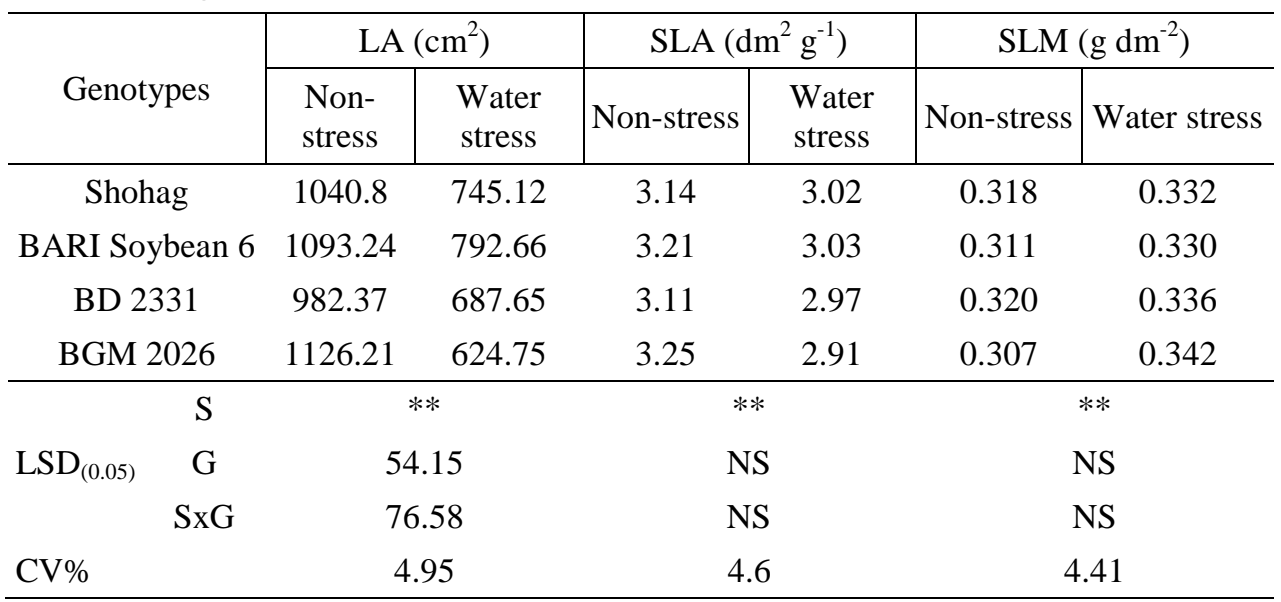

$\mathrm{S}=$ Stress, $\mathrm{G}=$ Genotypes, ** significant at $5 \%$ levels of probability, NS=not significant.

\section{Conclusion}

It is clear from this study that drought stress tolerance of genotypes Shohag, BARI Soybean 6, BD2331 was associated with higher photosynthetic efficiency and stomatal conductance, maintaining higher leaf area and lower transpiration rate and genotype BGM2026 showed lower tolerance to drought stress.

\section{References}

Alves, A.A.C. and T. L.Setter. 2004. Abscisic acid accumulation and osmotic adjustment in cassava under water deficit. Env. and Exp. Bot. 51: 259-271

Anjum, F., M. Yaseen, E. Rasul, A. Wahid and S. Anjum, 2003. Water stress in barley (Hordeum vulgare L.). I. Effect on chemical composition and chlorophyll contents, Pakistan J. Agr. Sci. 40: 45-49. 
Ashraf, M. and A. Iram. 2005. Drought stress induced changes in some organic substances in nodules and other plant parts of two potential legumes differing in salt tolerance. Flora. 200: 535-546.

Atteya, A. M. 2003. Alteration of water relations and yield of corn genotypes in response to drought stress. Bulg. J. Plant Physiol. 29: 63-76.

Barrios, A., G. Hoogenboom \& D. S. Nesmith . 2005. Drought stress and the distribution of vegetative and reproductive traits of a bean cultivar. Sci. agric. (Piracicaba, Braz.), 62: 18-22.

Boyer J. S. 1976. Photosynthesis at low water potentials. Philosophical transactions of the royal society. 273: 501-512.

Condon, A. G., G. D. Farqtihar and R. A. Richards. 1990. Genotypic variation in carbon discrimination and transpiration efficiency in wheat. Leaf gas exchange and whole plant studies. Aust. J. Plant Physiol. 17: 9-22.

Costa-Franca, M. G., A. T. P. Thi, C. Pimental, R. O. P. Rosseiello, Y. Zuily-Fodil and D. Laffray. 2000. Differences in growth and water relations among Phaseolus vulgaris cultivars in response to induced drought stress. Env. and Exp. Bot. 43: 227237.

De Souza P. I., D. B. Egli, W. P. Bruening. 1997. Water stress during seed filling and leaf senescence in soybean. Agron. J. 89: 807-812.

Farooq, M., A. Wahid, N. Kobayashi, D. Fujita, S. M. A. Basra. 2009. Plant drought stress: effects, mechanisms and management. Agron. Sustain. Dev. 29: 185-212.

$\mathrm{Fu}$, J. and B. Huang. 2001. Involvement of antioxidants and lipid peroxidation in the adaptation of two cool-season grasses to localized drought stress. Environ. Exp. Bot. 45: 105-114.

Gomez K.A. and A. A. Gomez. 1984. Statistical procedures for agricultural research, International Rice Research Institute, Los Banos, Philippines, John Wiley and sons, New York. Pp. 680.

Hagemeyer, J. 1997. Salt. In : Plant Ecoplysiology. Prasad, M. N. V. (ed.). John Wiley \& Sons. Inc. New York, Toronto Singapore. Pp. 174-205

Islam, M. S., M. M. Haque, M. M. Khan, T. Hidaka and M. A. Karim. 2004. Effect of fertilizer potassium on growth, yield and water relations of bushbean (Phaseolus vulgaris L.) under water stress conditions. Jpn. J. Trop. Agr. 48:1-9.

Kawamitsu, Y., T. Driscoll and J. S. Boyer. 2000. Photosynthesis during dessication in an Intertidal Alga and a Land Plant. Plant Cell Physiol. 41: 344-353.

Kolchevskii K. G., N. I. Kocharyan, O. Y. Koroleva. 1995. Effect of salinity on photosynthetic and ion accumulation in $\mathrm{C}_{3}$ and $\mathrm{C}_{4}$ plants of Ararat plain. Photosynthetica. 31: 277-282.

Ku, Y. S., W. K. A. Yeung, Y. L. Yung, M. W. Li, C. Q. Wen, X. Liu, and H. M. Lam. 2013. Drought Stress and Tolerance in Soybean. http://dx.doi.org/10.5772/52945.

Lawlor D. W. and G. Cornic. 2002. Photosynthetic carbon assimilation and associated metabolism in relation to water deficits in plants, Plant Cell Environ. 25: 275-294. 
Mafakheri A., A. Siosemardeh, B. Bahramnejad, P. C. Struik, Y. Shohrabi. 2010. Effect of drought stress on yield, proline and chlorophyll contents in three chickpea cultivars. Australian J. Crop Sci. 4: 580-585.

Makbul S., N. S. Guler, N. Durmus and S. Guven. 2011. Changes in anatomical and physiological parameters of soybean under drought stress. Turk J. Bot. 35: 369-377.

Monakhova, O. F. and I. I. Chernyadèv. 2002. Protective role of kartolin-4 in wheat plants exposed to soil drought. Appl. Biochem. Micro+. 38: 373-380.

Mondal, R. K. and N.K. Paul. 1992. Effect of irrigation on growth and some physiological characters of mustard (Brassica juncea L.). Bangladesh J. Agric. Res. 17: $29-36$

Nagy, Z. and G, Galiba. 1995. Drought and salt tolerance are not necessarily linked: a study on wheat varieties differing in drought tolerance under consecutive water and salinity stress. J. Plant Physiol. 145: 168-174.

Nobel, P. S., 1980. Interception of photosynthetically active radiation by cacti of different morphology. Oecologia. 45: 160-166.

Ocampo, E. T. M. and R. P. Robles. 2000. Drought tolerance in Mungbean II. Stomatal Movement, Photosynthesis and leaf water potential. Philipp. J. Crop Sci. 25: 7-15.

Purwanto, E. 2003. Photosynthesis activity of soybean (Glycine max L.) under drought stress. Agrosains. 5: 13-18.

Sibole, J. V., E. Momtero, C. Cabot, C. Poschenrieder and J. Barcelo. 1998. Role of sodium in the ABA-mediated long-term growth response of bean to salt stress. Physiol. Plant. 104, 299-305.

Silveira J. A. G., R. C. L. Costa, R. A. Viégas, J. T. A. Oliveira, M. V. B. Figueredo. 2003. N-compound accumulation and carbohydrate shortage on $\mathrm{N}_{2}$ fixation in drought-stressed and rewatered cowpea plants. Spanish J. Agril. Res. 1: 231-239.

Tardieu, F. and W. J. Davies. 1996. Root-shoot communication and whole plant regulation of water flux: water deficit in plants. Bios. Sci. publ. 147-162.

Unger, I. A. 1991. Effect of salts on vascular plants, Ecophysiology of vascular halophytes, CRC press, Boca. Raton. FL. Pp.108.

Van den Boogaard, R., M. de Boer, E. J. Veneklaas and H. Lanibers. 1996. Relative growth rate, biomas allocation pattern and water use efficiency of three wheat cultivars during early ontogeny as dependent on water availability. Physiologia Plantarum. 98: 493-504.

Wahid, A. and E. Rasul. 2005. Photosynthesis in leaf, stem, flower and fruit. In: Pessarakli M. (Ed.), Handbook of Photosynthesis, 2nd ed. CRC Press, Florida, Pp. 479-497.

Zhu, J. K. 2002. Salt and drought stress signal transduction in plants. Annual Review of plant Biology. 53: 247-273 